International Journal of Business and Management Review

Vol.8, No.5, pp.1-14, July 2020

Published by ECRTD-UK

Print ISSN: 2052-6393(Print), Online ISSN: 2052-6407(Online)

\title{
EFFECT OF RECRUITMENT AND SELECTION PRACTICES ON JOB SATISFACTION OF SECURITY PERSONNEL IN PUBLIC SECONDARY SCHOOLS IN BARINGO COUNTY, KENYA
}

\author{
Sharon Jerotich Koech, ${ }^{1}$ Ronald K. Chepkilot, ${ }^{2}$ Maina Waiganjo ${ }^{3}$ \\ School of Business and Economics, Kabarak University \\ Correspondent author's email: sharonkoech@yahoo.com
}

\begin{abstract}
Security officers are part of the non-teaching staff in schools and school managers expect them to be productive, dedicated, disciplined and committed to their work. Studies carried out in other countries have revealed that human resource management practices have profound effects on the job satisfaction of security personnel. Therefore, the purpose of this study was to examine the effect of human resource management practices on the job satisfaction of security personnel in public secondary schools in Baringo County, Kenya. This paper presents and discusses the research findings on the effect of recruitment and selection practices on job satisfaction of security personnel in public secondary schools in Baringo County. It targeted 508 security personnel and 169 principals in public secondary schools in Baringo County. Slovin's formula was used to get the sample of 224 security personnel. Random sampling technique was used to select $10 \%$ of the school principals to participate in the study. A questionnaire and an interview guide were used to collect data. These research tools were validated and then tested for reliability. Cronbach Alpha was used to test reliability. The reliability of the instrument was 0.788 , which was above the 0.70 threshold of acceptable reliability. Qualitative data was analysed thematically based on the objectives. Quantitative data was collected and analysed by use of both descriptive (means, percentages as well as frequencies) and inferential statistics. The inferential statistics comprised Pearson product moment correlation and multiple linear regression. The results from the research revealed that recruitment and selection practices $(\beta 2=0.322, p<0.05)$ had significant effect on security personnel's job satisfaction. Therefore, recruitment and selection practices were found to be major predictors of job satisfaction. The researcher concluded that the Recruitment and selection practices were significant determinants of security personnel's job satisfaction. It is therefore recommended that school Boards of Management should clarify the requisite skills and qualification for security personnel. They should advertise vacancies for security jobs and avoid recruiting personnel only from the school neighbourhood. They should ensure they select the right candidates for the right job.
\end{abstract}

KEYWORDS: effect, recruitment, selection practices, job satisfaction, security personnel, public secondary schools, Baringo County, Kenya

\section{INTRODUCTION}

Human resource management practices are aimed at improving the overall performance of employees within the organization, ultimately resulting in increased organizational performance 
International Journal of Business and Management Review

Vol.8, No.5, pp.1-14, July 2020

Published by ECRTD-UK

Print ISSN: 2052-6393(Print), Online ISSN: 2052-6407(Online)

via job satisfaction. Efficient human resource management strategies offer supportive work situations that allow every member to advance. As a result, the organization profits from the service quality provided by competent loyal employees. These positive outcomes are founded on a philosophy that people are an asset and that investing in them and making sure they are satisfied at their workplace will bring increased benefits for the entire organization (Joshi, 2013). Tarigan and Ariani (2015) established a positive correlation of organisational commitment with job satisfaction. In their work, they deduce that success of organizations may depend on the level of job satisfaction and commitment of its employees. An employee who is committed to the organization has a tendency to perform more efficiently compared to an employee who is not. This is because such dedication may be as a result of working conditions, association with the aims and objectives of the organisation or simply as a result of no other viable alternative (Shieh, 2014). Additionally, job satisfaction has been found to significantly influence such behaviours as lateness to work and ineffectiveness among employees (Tarigan \& Ariani, 2015). This suggests that human resource management practices are central to the improvement of the quality of services offered by organizations.

In the Kenyan context, very little research has focused on the job satisfaction of school security personnel. Some of the related studies include that by Ngeny, Bonuke and Kiptum (2017) who examined the effect of working environment on job satisfaction among non-teaching staff in secondary schools in Keiyo South Sub-County, Kenya. The researchers demonstrated that remuneration has a positive and significant effect on job satisfaction. The study further observed that an employee would not be satisfied with their job if they believe that others working in the same institution with similar qualifications earn more than them. The authors suggest that employees should have an opportunity for career advancement, which includes the provision of a clear scheme of service where staff can utilize their talents and skills as they progress in the school setting. In so doing, learning institutions will promote a healthy and secure workplace that will bolster the job satisfaction levels of the non-teaching staff. A few scholars have documented the effects of human resource management practices on job satisfaction in the security sector. For instance, Kemboi and Moronge (2016), in their study of the determinants of employee job satisfaction in public security sector in Kenya, found that employee benefits, work environment as well as training and development affect job satisfaction. However, their study was specifically on the national police service and not in public secondary schools.

\section{Effect of Recruitment and Selection on Job Satisfaction}

Recruitment and selection practices in human resource management are generally informed by the company's mission and culture. Recruitment and selection is the process of attracting individuals on a timely basis, in sufficient numbers and with appropriate qualifications. It is actually the procedure involved in identification of candidates for employment and encouraging them to express interest for positions in an organization (Chhabra, 2005). Both of these processes involve marking out, inviting and picking out the appropriate individuals to help in realising the company's human resource needs. They are mainly concerned with finding, assessing, and engaging new employees or promoting existing ones. The focus is on fitting the capacities and desires of potential employees with the needs and promises of a specific office. Recruitment and selection decisions are among the most important of all decisions that managers have to make 
International Journal of Business and Management Review

Vol.8, No.5, pp.1-14, July 2020

Published by ECRTD-UK

Print ISSN: 2052-6393(Print), Online ISSN: 2052-6407(Online)

because they are a pre-requisite to the development of an efficient workforce.

According to Gamage (2014), recruitment and selection are critical areas of human resource management in every organization. The value of the human resources the organization has majorly stems from these functions. The author further argues that the general purpose of recruitment and selection is to avail the company with a group of most relevant office candidates. Indeed, the overall aim of the two processes within the organization is to obtain the right kind of necessary to meet the strategic goals of the employer with the least possible cost (Ofori \& Aryeetey, 2014). Patimah (2015) suggests that recruitment and selection have positive relationship with employees' productivity, employees' commitment and work quality in the organization.

Foot and Hook (2010) recognize the key stages of an orderly style to staffing and selection as job analysis, job explanation and specification of persons and encourage interviewees through the several approaches of staffing. The three main phases, according to them, are job analysis, job description and individual requirement. Research has shown that implementing an effective staffing process is positively related to organizational performance (Syed \& Jama, 2012). According to Bohlander and Snell (2010), selection is a well-organized procedure of selecting applicants who have the required experience and qualification to fill vacant position in an organization. These researchers explain recruitment and selection as the procedure for choosing the persons from the pool of probable applicants who meet the prerequisite of the vacant position recognized in the institute.

The work of Gopinath and Shibu (2014), on recruitment and selection in relation to job satisfaction, reveals that human resource planning is the most critical element of personnel functions. Consequently, the work of gathering the right kind of employees belongs to the Human Resources Management (HRM). A large number of potential workforces are available in the employment market, but the challenge for organizations is to identify and select those candidates who could perform effectively and efficiently. The research highlighted that the starting point in any recruitment process is an accurate analysis of the job. Selection and the assessments chosen for the identification work should be done on the basis of the demands of the particular office.

Knowledge is critical for any company, especially regarding the indicators of good job output; what kind of knowledge, skills and abilities are required and what measures would be effective in assessing these (Gopinath \& Shibu, 2014). Normally, the focus of recruitment and selection is to match the capabilities of potential candidates against the demands and rewards inherent in a given job. As such, highly productive companies spend huge sums of money and time putting in place highly accurate selection structures. The value of fresh recruits is subject to the organization's recruitment processes, and the effectiveness of the selection phase is critically reliant on the type of potential employees that are attracted. Evidentially, recruitment and selection is of principal importance to job satisfaction in order to get the best of employees.

Recruitment and selection influence the staff output and subsequently inspire job satisfaction. It is argued that the act of bringing in new workers is not just to substitute those who are leaving or supplement existing workforce, but also to acquire resources that can give high output and exhibit commitment, thereby leading to high level of job satisfaction (Ballantyne, 2014). Moreover, 
International Journal of Business and Management Review

Vol.8, No.5, pp.1-14, July 2020

Published by ECRTD-UK

Print ISSN: 2052-6393(Print), Online ISSN: 2052-6407(Online)

recruitment and selection play a vital function of influencing an organization's niche and performance. The acquisition of new employees aids in modelling a company's dreams, underscoring the competencies to it prioritises, hence raising the level of job satisfaction. It also acts as a framework for informing the public about the company's values and accomplishments. This being the case in other countries, in Kenya, specifically Baringo County, the current study sought to explore how recruitment and selection affect job satisfaction among security workers in schools.

The existing literature is replete with evidence indicating that there is a positive and significant relationship between recruitment and selection and the performance of an organization. For instance, the work of Syed and Jama (2012) has shown that deploying a recruitment and selection procedure is positively linked to a company's overall output. This is because the recruitment and selection process determines the decision as to which candidates get employment offers (Otieno, 2013). The core purpose of this process is to increase the fit between workers and the company, groups, and office responsibilities and thus to set up a good work environment (Tzafrir, 2006). Without a doubt, a sophisticated recruitment and selection system can ensure a better fit between the individual's abilities and the organization's requirement (Otieno, 2013). Nyabuto (2017) concluded that employment stability could be achieved through a selection procedure based on ability.

Omolo (2012) investigated the influence of recruitment and selection on the productivity of small and medium enterprises (SMEs) in Kisumu Municipality in Kenya. They report that the general mean output of SMEs in the areas was $60.71 \%$. Further, the investigation found a significant positive link between recruitment and selection, on the one hand, and overall output of SMEs, on the other, at $\alpha=.01$. The average output of these enterprises with good recruitment and selection was $81.90 \%$; with moderate at $67.94 \%$ and poor at $53.90 \%$. Recruitment and selection contributed up to $40.8 \%$ of the total change in their output. The study deduced that recruitment and selection do critically affect the productivity of SMEs. Though the study was done in Kenya, it mainly investigated the influence of recruitment and selection on the performance of SMEs and not on job satisfaction among school security personnel, which was the focus of the current study.

In a study to establish the influence of recruitment and selection on the productivity of workers of research institutes in Kenya, Kepha, Mukulu and Waititu (2012) indicated that the link between workers' output and recruitment and selection is highly significant. The author advices that these institutes need to abide strongly with job specifications when hiring new staff. This view is shared by Agoi, Namusonge and Iravo (2018) in their research on the effect of recruitment and selection practices on employee satisfaction in publicly-owned sugar manufacturing firms in western Kenya. They established that recruitment and selection of employees is critical to the existence of any organization. They contend that the recruitment of staff in an appropriate manner is beneficial since it helps to avoid consequences such as high staff turnover and poor performance. The current study sought to ascertain whether recruitment and selection affects job satisfaction among security personnel in public schools in Baringo County. 
International Journal of Business and Management Review

Vol.8, No.5, pp.1-14, July 2020

Published by ECRTD-UK

Print ISSN: 2052-6393(Print), Online ISSN: 2052-6407(Online)

\section{Statement of the Problem}

The role of school security personnel in enhancing the safety of students, staff and the school property is pivotal. This is because security personnel form the cornerstone of a safe school environment. They are part of the non-teaching staff in schools in Kenya and school managers expect them to be productive, dedicated, disciplined and committed to their work. Therefore, for these officers to function as expected, they would be expected to be a satisfied workforce. However, in Baringo County, there is apparent job dissatisfaction among security personnel in secondary schools going by the manifestations of unprecedented insecurities reported in recent years.

The systems audit report released in 2018 revealed many security gaps in public secondary schools. The report indicated rampant cases of absenteeism, drunkenness, tending to personal businesses during work time, high turnover rates, ineffectiveness, lateness and collusion with students to abet crimes, such as allowing students to sneak out of school, supplying drugs and alcohol as well as pilferage of school items among schools' security personnel. The report also showed that many security personnel in schools in the County are exiting their profession due to job dissatisfaction. The turnover rate of security personnel in the county was estimated at $26 \%$ per year (Kirui, 2018). While the real reasons for this phenomenon are yet to be known, research done in other parts of the world shows that job satisfaction has direct relation to employee work behaviours such lateness, absenteeism, commitment, turnover, performance and productivity of security guards, correctional officers and police officers (Mushtaq, Ahmad \& Shatif, 2015). It has also been shown that employee satisfaction improves retention levels and reduces the cost of recruitment and training (Benson \& Brown, 2010; Dunham \& Alpert, 2015).

In addition, over 47 cases of school unrests in Baringo County schools have been reported within a period of five years. This implies that $28 \%$ of the public schools in the County have been victims of unrest (County Director of Education [CDE], 2018). If this scenario is not investigated, the insecurity problem will continue, and the failure to maintain security personnel for long may lead to increased unrests and insecurity in schools. The cost of replacing support staff in schools is also high. Furthermore, security is a sensitive matter and frequent changes of security personnel may weaken the security systems further. The wider impact is that public resources will continue being wasted and the lives of both students and staff remain at risk, both of which will negatively affect the economic development of the County.

Several studies have revealed that there are many push and pull factors influencing employee satisfaction. These studies have shown that human resource management practices such as remuneration, work-life balance; work environment, employee relations, job design, recruitment and selection enhance employee satisfaction (Ngeny et al., 2017; Kiptum, Mandela \& Murira, 2018). In secondary schools, research focus on job satisfaction has mainly been on the teaching staff whose issues are handled by hired Teachers Service Commission (TSC) professionals and a few on non-teaching staff whose issues are handled by school Board of management who may not have the HRM skills required to execute their mandate in schools. As such, HRM practices used by schools' managers were investigated to see the extent to which they affect job satisfaction of 
school security personnel in Baringo County. In particular, the study focused on the effect of recruitment and selection on job satisfaction of school security personnel.

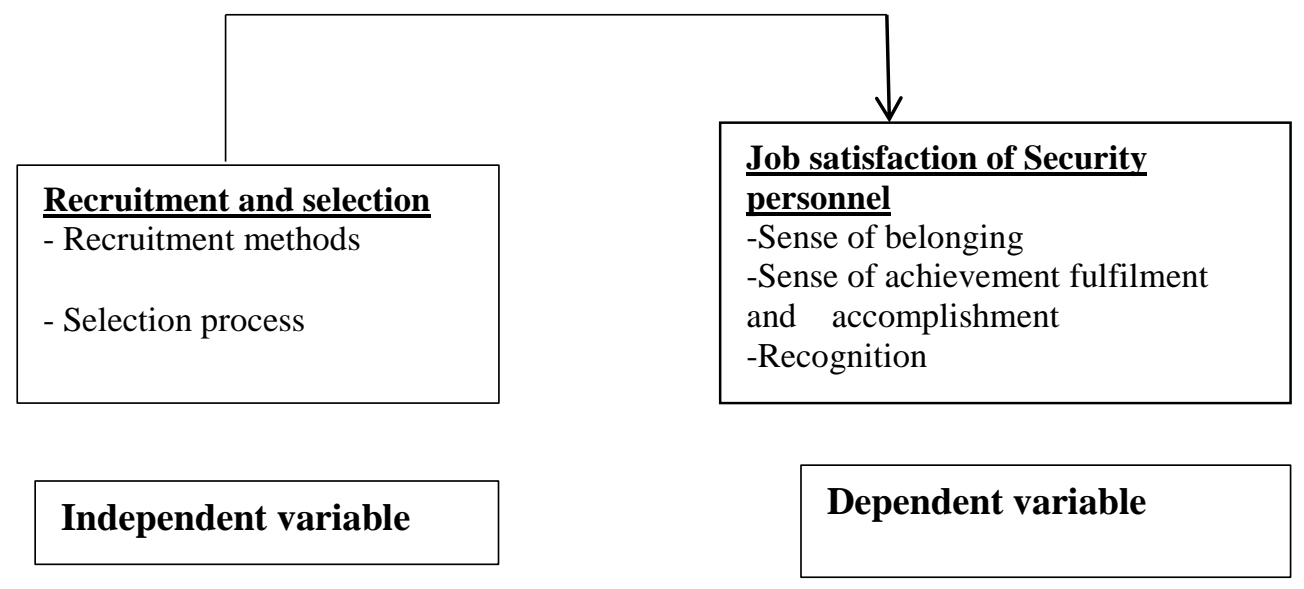

\section{Figure 1: Conceptual Framework}

\section{Materials and Methods}

This research study was conducted through an explanatory survey research design. It was carried out in public secondary schools in Baringo County, Kenya. Baringo County was chosen because there is a paucity of knowledge on the effect of HRM practices on job satisfaction of security personnel in schools in the area. Moreover, there has been rampant cases of security personnel's dissatisfaction that has been manifested throughout the County, majorly through absenteeism, turnover, stress, unrests, and workload among others in the study area (County Director of Education [CDE], 2019). At the time of the study, the County had 169 public secondary schools, 169 principals and 508 school security personnel. Stratified sampling technique was used to ensure that all the six sub-counties (namely Eldama Ravine, Mogotio, Baringo South, Tiaty, Baringo Central and Baringo North) were included in the study. The sample size of the security personnel was determined using the Slovin's formula (Dionco-Adetayo, 2011) as shown below.

$$
\begin{array}{ll}
\mathrm{n}=\frac{\mathrm{N}}{1+\mathrm{NE}^{2}} & \\
\text { Where: } & \mathrm{n}=\text { sample size } \\
& \mathrm{N}=\text { population size } \\
& 1=\text { is a constant value } \\
& \mathrm{E}=\text { margin of error } * \text { desired }
\end{array}
$$

Hence:

$$
\begin{aligned}
& \mathrm{n}=508 / 1+508(0.05) 2 \\
& \mathrm{n}=508 / 2.27=223.7=224
\end{aligned}
$$

Therefore, the sample size of the security personnel, allowing a 5\% error margin, was 224 given that the accessible population was 508. The sample size was as shown in Table 1 below. 
International Journal of Business and Management Review

Vol.8, No.5, pp.1-14, July 2020

Published by ECRTD-UK

Print ISSN: 2052-6393(Print), Online ISSN: 2052-6407(Online)

\begin{tabular}{lll} 
Table 1: Distribution of Security Personnel Sample by Sub-counties \\
\hline Sub-county & $\begin{array}{l}\text { Population of security } \\
\text { Personnel }\end{array}$ & $\begin{array}{l}\text { Sample size of security } \\
\text { personnel }\end{array}$ \\
\hline Eldama Ravine & 114 & 50 \\
Mogotio & 76 & 34 \\
Baringo South & 70 & 31 \\
Tiaty & 26 & 11 \\
Baringo Central & 126 & 56 \\
Baringo North & 96 & 42 \\
Total & $\mathbf{N}=\mathbf{5 0 8}$ & $\mathbf{n = 2 2 4}$ \\
\hline
\end{tabular}

Source: County Director of Education Baringo County (CDE) (2019)

In the study, two research instruments were used to collect data from the respondents, namely the questionnaire and interview schedule. The data gathered from questionnaires were validated, edited and then coded. The validation process enabled the researchers to determine the return rate of questionnaires. Editing and coding of the collected information was done before the data was entered into the Statistical Package for Social Scientists tool (SPSS). The quantitative data collected were analysed using both descriptive statistics (specifically percentages and frequencies) and inferential statistics (correlation and regression analysis). Pearson moment correlation and multiple linear regression were was used to test hypotheses at alpha level $(\alpha=0.05)$. The Pearson Moment correlation was used because it is ideal for establishing the strength and direction of association of variables. Regression analysis displays how well the variables of the study are able to predict a particular outcome.

\section{RESULTS AND DISCUSSION}

The research results revealed that majority of the respondents (111) agreed that job applicants were fully informed about the qualifications required to perform the job before being hired. Another 47 respondents strongly agreed with this statement. However, few (28) disagreed with the assertion. The researcher thus deduced that, on average (Mean=3.84, $\mathrm{SD}=1.11)$, applicants are fully informed about the qualifications required to perform the job before being hired. Majority (121) also agreed that the curriculum vitae, references and qualifications were checked thoroughly before being appointed as security officers. There were also others (30) who strongly agreed with the statement. However, a few (13) disagreed while 19 strongly disagreed with the statement. Therefore, on average (Mean=3.67, SD =1.12), the curriculum vitae, references and qualifications were checked thoroughly before appointing applicants as security personnel in schools.

Out of the 194 respondents, 98 strongly disagreed that applicants underwent a medical test before being hired, 53 also disagreed with the statement while only 15 agreed and others (15) strongly agreed. As such, on average (Mean=1.94, $\mathrm{SD}=1.26)$, of the respondents did not undergo a medical test before being hired. Out of 194 respondents, majority (72) agreed that vacancies were filled from qualified employees; another 18 strongly agreed that vacancies were filled while the rest disagreed. The researcher thus deduced that, on average (mean=3.45, SD=1.06), vacancies were filled, 110 respondents agreed that applicants underwent structured interviews (job-related 
International Journal of Business and Management Review

Vol.8, No.5, pp.1-14, July 2020

Published by ECRTD-UK

Print ISSN: 2052-6393(Print), Online ISSN: 2052-6407(Online)

questions, same questions asked of all applicants) before being hired. Moreover, 37respondents strongly agreed with the statement while only a few (21) disagreed and 22 strongly disagreed. The researcher thus deduced that, on average (Mean=3.62, SD=1.24), the applicants underwent structured interviews before being hired. On the other hand, majority of the respondents (78) strongly disagreed that applicants for the job took formal tests (written or work sample) for selecting applicants to fill existing vacancies, 76 more respondents disagreed with the statement while only a few (34) agreed. It was, therefore, concluded that, on average (Mean=2.02, SD=1.20), applicants for the school security personnel job did not take formal tests (written or work sample) for selecting applicants for vacancies.

Majority (72) nonetheless agreed that candidates were selected on the basis of their competency and qualification, 33 strongly agreed with the statement while 58 were not sure. Generally, the respondents agreed that candidates were selected on the basis of their competency and qualification. Majority (114) were not sure with irregularities regarding the selection of candidates and whether or not they could be freely reported without fear of victimization. However, 17 respondents agreed while 21 disagreed with the statement, hence the researcher could not deduce the perception of the respondent with irregularities regarding the selection of candidates being freely reported without fear of victimization. However, the information from the interviews with the principals indicated that the decisions of the BOM on who was selected was final. Majority (65) also disagreed that they were involved in the selection process. Another (59) respondents strongly disagreed while only a few (25) agreed with the statement. The researcher thus deduced that, on average (Mean=2.20, $\mathrm{SD}=1.09$ ), the respondents disagreed that they were involved in the selection processes. Majority (95), however, agreed that advertisements for vacancies should cater for employment equity. On the same issue, 48 more respondents strongly agreed while only a few (14) disagreed. As such, the researcher concluded that, on average (mean=3.84, SD=1.02), the respondents agreed that advertisements for vacancies should cater for employment equity. These findings were as presented in Table 2 below. 
International Journal of Business and Management Review

Vol.8, No.5, pp.1-14, July 2020

Published by ECRTD-UK

Print ISSN: 2052-6393(Print), Online ISSN: 2052-6407(Online)

Table 2: Recruitment and Selection Practices

\begin{tabular}{|c|c|c|c|c|c|c|c|c|}
\hline & \multicolumn{3}{|c|}{ Strongly } & \multirow[b]{2}{*}{ Not sure } & \multicolumn{3}{|c|}{ Strongly } & \multirow{2}{*}{$\begin{array}{c}\text { Std. } \\
\text { Deviation }\end{array}$} \\
\hline & $\mathrm{N}$ & Disagree & Disagree & & Agree & Agree & Mean & \\
\hline $\begin{array}{l}\text { Applicants are fully informed about } \\
\text { the qualifications required to perform } \\
\text { the job before being hired }\end{array}$ & 193 & 15 & 13 & 7 & 111 & 47 & 3.84 & 1.11 \\
\hline $\begin{array}{l}\text { The curriculum vitae, references and } \\
\text { qualifications are checked thoroughly } \\
\text { before appointing a candidate }\end{array}$ & 193 & 19 & 13 & 10 & 121 & 30 & 3.67 & 1.12 \\
\hline $\begin{array}{l}\text { Applicants undergo a medical test } \\
\text { before being hired }\end{array}$ & 192 & 98 & 53 & 11 & 15 & 15 & 1.94 & 1.26 \\
\hline $\begin{array}{l}\text { Vacancies are filled from qualified } \\
\text { employees }\end{array}$ & 192 & 14 & 14 & 64 & 72 & 28 & 3.45 & 1.06 \\
\hline $\begin{array}{l}\text { Applicants undergo structured } \\
\text { interviews (job related questions, } \\
\text { same questions asked of all } \\
\text { applicants)before being hired }\end{array}$ & 191 & 22 & 21 & 1 & 110 & 37 & 3.62 & 1.24 \\
\hline $\begin{array}{l}\text { Applicants for this job take formal } \\
\text { test (written or work sample)for } \\
\text { selecting applicants for vacancies }\end{array}$ & 191 & 78 & 76 & 3 & 23 & 11 & 2.02 & 1.20 \\
\hline $\begin{array}{l}\text { Candidates are selected on the basis } \\
\text { of their competency and qualification }\end{array}$ & 191 & 16 & 12 & 58 & 72 & 33 & 3.49 & 1.11 \\
\hline $\begin{array}{l}\text { Irregularities regarding the selection of } \\
\text { candidates can be freely } \\
\text { reported without fear of victimization }\end{array}$ & 192 & 35 & 21 & 114 & 17 & 5 & 2.67 & 0.96 \\
\hline $\begin{array}{l}\text { We are involved in a selection } \\
\text { process }\end{array}$ & 187 & 59 & 65 & 34 & 25 & 4 & 2.20 & 1.09 \\
\hline $\begin{array}{l}\text { Advertisements for vacancies } \\
\text { should cater for employment equity }\end{array}$ & 192 & 8 & 14 & 27 & 95 & 48 & 3.84 & 1.02 \\
\hline
\end{tabular}

Source: Survey data (2019)

Recruitment and selection processes tend to determine the decision which candidates get employment offers (Otieno, 2013). Normally, the aim of this practice is to improve the fit between employees and the organization, teams and work requirements and to subsequently create a better work environment (Tzafrir, 2006). Furthermore, well-structured recruitment and selection systems can ensure a better fit between the individuals' abilities and the organization's requirements (Otieno, 2013). However, poor recruitment decisions continue to affect organizational employee retention. In most cases, mistakes are caused by the fact that organisations generally give little thought to the critical nature of staffing decisions and make little or no attempt to validate recruitment practices.

Gopinath and Shibu (2014) agree that recruitment and selection processes are important practices for human resource management, and are crucial in effecting organizational success. The quality of new recruits depends on an organization's recruitment practices, and the relative effectiveness of the selection phase is inherently dependent on the calibre of candidates attracted. In effect, recruitment and selection is one area of prime importance to job satisfaction in order to get the best of employees, but employers face lots of challenges in their quest to recruit the right workforce. 
International Journal of Business and Management Review

Vol.8, No.5, pp.1-14, July 2020

Published by ECRTD-UK

Print ISSN: 2052-6393(Print), Online ISSN: 2052-6407(Online)

\section{Correlation of Recruitment and Selection Practices and Job Satisfaction of Security Personnel}

In the study, Pearson moment correlation was used to establish the effect of recruitment and selection practices on job satisfaction of security personnel in public secondary schools in Baringo County. The findings were as shown in Table 3 below.

Table 3: Pearson Moment Correlation for Selection Practices and Job Satisfaction

\begin{tabular}{llr}
\hline Scale & & Satisfaction Level \\
\hline Recruitment and Selection & Pearson & $.338^{* *}$ \\
Practices & Correlation & .000 \\
& Sig. (2-tailed) & 194 \\
& $\mathrm{~N}$ & \\
Correlation is significant at the 0.05 level (2 tailed)
\end{tabular}

Source: Survey data (2019)

Table 3 shows that there was a positive and statistically significant relationship between recruitment and selection practices and level of job satisfaction $\left(\mathrm{r}=.338^{* *}, \mathrm{p}<0.000\right)$. Therefore, the results revealed a significant relationship between recruitment and selection practices and level of job satisfaction among security personnel in public secondary schools in Baringo County. From these findings, it was deduced that enhancement of recruitment and selection practices would lead to an increase in levels of job satisfaction among security personnel in public secondary schools. Though the strength of relationship was moderate, the relationship was seen as significant ( $\mathrm{p}<$ 0.05), meaning that recruitment and selection practices have a significant positive linear association with levels of job satisfaction among security personnel in public secondary schools. These results thus negated the null hypothesis which stated that there is no statistically significant relationship between recruitment and selection practices and level of job satisfaction among security personnel in public secondary schools in Baringo County.

This findings concurred with those of Omari, K'Obonyo and Kidombo (2012), in their study on the importance of training and development on the performance of Public Water Utilities in Tanzania. They reported that recruitment and selection practices have a positive relationship with job satisfaction. Similar findings were reported by Macharia and Omondi (2016) whose study on the relationship between human resource management practices and employee job satisfaction in Kenyatta University, Kenya, found that job description and job specifications are used in employee recruitment processes. The authors also observed that the institution selects employees with the desired knowledge, skills and attitudes.

The current study findings also confirmed the findings of Agoi (2016) who observed that in order for organizations to reap the benefits of the recruitment and selection of staff and, in turn, enhance employee satisfaction, it is important that they highlight the skills and attitudes to which they attach the highest priority. This is because once an institution has undertaken recruitment, the new employees need to be appraised and developed to ensure they are well-versed with knowledge on new trends and challenges. Interviews with school principals showed that security guards also 
Vol.8, No.5, pp.1-14, July 2020

Published by ECRTD-UK

Print ISSN: 2052-6393(Print), Online ISSN: 2052-6407(Online)

recruited from the surrounding communities because the locals were believed to be experienced and conversant with the school surroundings.

\section{Regression of Recruitment and Selection Practices on Job Satisfaction of Security Personnel}

The study hypothesised that there is no statistically significant effect of recruitment and selection on job satisfaction of security personnel in public secondary schools in Baringo County, Kenya. This section provides the statistics of the respondents' opinions concerning recruitment and selection practices of security personnel in public secondary schools in Baringo County, Kenya. The researcher asked 10 questions that were key indicators of the status of recruitment and selection practices. The research established that recruitment and selection practices significantly affected the level of job satisfaction $(B=0.322$, Sig. $<0.05)$. The coefficient of 0.322 was significantly different from zero since $p$ value $<0.05$. As such, the null hypothesis was rejected. The study thus found that a unit enhancement in recruitment and selection practices resulted in $32.2 \%$ increase in job satisfaction. These findings were as presented in Table 4 below.

Table 4: Regression of Job Satisfaction on Recruitment and Selection Practices

\begin{tabular}{|c|c|c|c|c|c|}
\hline \multirow[t]{2}{*}{ Model } & \multicolumn{2}{|c|}{$\begin{array}{l}\text { Unstandardized } \\
\text { Coefficients }\end{array}$} & \multirow{2}{*}{$\begin{array}{l}\text { Standardized } \\
\text { Coefficients } \\
\text { Beta }\end{array}$} & \multirow[t]{2}{*}{$\mathbf{t}$} & \multirow[t]{2}{*}{ Sig. } \\
\hline & B & $\begin{array}{l}\text { Std. } \\
\text { Error }\end{array}$ & & & \\
\hline (Constant) & 26.185 & 2.035 & & 12.866 & .000 \\
\hline $\begin{array}{l}\text { Recruitment and } \\
\text { Selection Practices }\end{array}$ & .322 & .065 & .338 & 4.981 & .000 \\
\hline a. Dependent Variable & atisfacti & & & & \\
\hline
\end{tabular}

Source: Survey data (2019)

It is evident from the regression analysis that recruitment and selection practices affect job satisfaction significantly $(\beta=.322, \mathrm{p}<0.05)$. Therefore, the researcher rejected the null hypothesis and accepted that recruitment and selection practices had a significant effect on job satisfaction. This implied that for each unit increase in recruitment and selection practices, there was 0.322 unit increase in job satisfaction of security personnel. The effect of recruitment practices was shown by the t-value of 4.981, which indicated that the standard error associated with the parameter was less than the effect of the parameter. This view agreed with those Ballantyne (2014) who notes that selection of employees aims to put in place workers who are able to perform at a high level and demonstrate commitment hence leading to high level of employee satisfaction. Basically, recruitment and selection of employees is fundamental to employee satisfaction within an organization.

The results also corroborated those of Irungu, Njongoro and Kariuki (2019), in their study on the influence of recruitment and selection approaches on staff retention in faith-based organizations in Kibera Sub-County in Nairobi County. Irungu et al. observed that the nature of recruitment and selection approaches tends to determine the extent to which employees are retained in an organization. These authors also noted that practices like good and vivid clarification of the 
International Journal of Business and Management Review

Vol.8, No.5, pp.1-14, July 2020

Published by ECRTD-UK

Print ISSN: 2052-6393(Print), Online ISSN: 2052-6407(Online)

required skills for any given vacancy and consideration of internal recruitment were quite necessary in an organization.

\section{CONCLUSION}

From the results of the study, recruitment and selection of employees constitute crucial HRM practices for the survival of any organization. The recruitment of staff in a desirable manner is beneficial since it averts negative organizational behaviours from employees, for instance, high staff turnover and poor performance. The study however revealed that recruitment practices affect employee satisfaction. Further, the nature of recruitment and selection approaches tends to determine the extent to which employees are retained in an organization. Practices like good and vivid clarification of the required qualifications and skills for any given vacancy and consideration of fairness and equity in the selection process are quite necessary in any organization to realize its manpower objectives. Conversely, this study further revealed that some security personnel were employed based on political affiliations and rewards. Moreover, most security personnel comprise untrained people sourced from the surrounding school communities while others are officers discharged previously from police service based on various grounds. Therefore, there is need for further research on the challenges of recruitment and selection of security personnel in schools to augment the findings of this research.

\section{Implications of the Findings to Research and Practice}

In order for public secondary schools to reap the benefits of the recruitment and selection of security personnel and, in turn, enhance these employees' job satisfaction, schools boards of management should highlight the knowledge, skills and attitudes to which they attach the highest priority among security personnel. The boards should adopt appropriate recruitment and selection policies so that they can have exceptional security personnel. Once a school has undertaken recruitment and selection of security personnel, the new employees need to be inducted and given training on the unique security challenges and needs of the school. In so doing, growth of the institution as well as employees' job satisfaction will be enlisted and sustained. Schools should also employ more security personnel to avoid overworking the existing guards.

In relation to policy, it is recommended that recruitment and selection of security personnel should be done in a desirable manner. There should be provision of skills clarity and skills diversification. Schools should advertise vacancies for security jobs and avoid localizing recruitment and selection. They should ensure they select the right candidates for the right job and observe the equal employment opportunity principle. The recruited guards should be appraised and developed so that they are well-versed with new security trends. Security personnel are among the essential support staff in schools. As such, they should be employed on permanent and pensionable terms and follow set norms in engaging other categories of staff. They should also be recruited based on the number of streams in a school.

\section{REFERENCES}

Agoi, L. F. (2016). Influence of human resource management practices on employee satisfaction in public sugar manufacturing firms in Kenya (Unpublished Doctoral Thesis). Jomo Kenyatta University. 
International Journal of Business and Management Review

Vol.8, No.5, pp.1-14, July 2020

Published by ECRTD-UK

Print ISSN: 2052-6393(Print), Online ISSN: 2052-6407(Online)

Agoi, L. F., Namusonge, G. S., \& Iravo, A. (2018). Effect of recruitment and selection practices on employee satisfaction in publicly owned sugar manufacturing firms in western Kenya. International Journal of Current Research, 8(2), 26320-26326.

Ballantyne, I. (2014). Recruiting and selecting staff in organizations. In S. Gilmore and S. Williams (Eds.), Human Resource Management. Oxford: Oxford University Press.

Benson, J., \& Brown, M. (2010). Employee voice: does union membership matter? Human Resource Management Journal, 20(1), 80-99.

Bohlander, G., \& Snell, S. (2010). Managing Human Resources. Mason, OH: South-Western Cengage Learning.

Chhabra, T. N. (2005). Human Resources Management concepts and issues. New Delhi: Dhanpat Rai \& Co. Ltd.

County Director of Education (CDE) (2018). Status report on Students' Unrest $1^{\text {st }}$ and $2^{\text {nd }}$ term Baringo County. Unpublished document.

County Director of Education (CDE) (2019). Statistics on Schools and Tertiary Institutions in Baringo County. Baringo County CDE.

Dionco-Adetayo, E. (2011). Guide to business research and thesis writing (2 ${ }^{\text {nd }}$ ed.). Ibadan: Rasmed Publications.

Dunham, R. G., \& Alpert, G. P. (2015). Critical issues in policing: Contemporary readings. Waveland Press.

Foot, M., \& Hook, C. (2010). Introducing human resource management. London: Pearson Education (UK).

Gamage, A. S. (2014). Recruitment and selection practices in manufacturing SMEs in Japan: An analysis of the link with Business performance. Ruhuna Journal of Management and Finance, 1(1), 37-52.

Gopinath, R., \& Shibu, N. (2014). Recruitment and selection influencing job satisfaction - A study with reference to BSNL. Madurai SSA.

Irungu, L. N., Njongoro, M., \& Kariuki, E. (2019) Influence of recruitment and selection approaches on staff retention in faith- based organizations: A case of ACK Kibera paper project, Kibra Sub-County in Nairobi County. The Strategic Journal of Business \& Change Management, 6(1), 1-16.

Joshi, M. (2013). Human Resource Management ( $1^{\text {th }}$ ed.). Bookboon.com

Kemboi, P. C., \& Moronge, M. (2016). Determinants of employee job satisfaction in public security sector in Kenya: A case of national police service. Strategic Journal of Business and Change Management, 3(2), 659-688.

Kepha, O., Mukulu, E., \& Waititu, A. (2012). The influence of recruitment and selection on the performance of employees in research institutes in Kenya. International Journal of Science and Research (IJSR), 3(5), 132-138.

Kiptum, J. K., Mandela, R. O., \& Murira, F. N. (2018). An assessment of how environment influence teachers' satisfaction in Elgeyo Marakwet County. The international journal of Humanities and Social Studies, 6(6), 265-272.

Kirui, K. (2018). Systems audit report - Baringo County (27 $7^{\text {th }}$ February-9 $9^{\text {th }}$ March, 2018). Unpublished document.

Macharia, E. W., \& Omondi, M. (2016). Relationship between human resource management practices and employee job satisfaction in public universities in Kenya: a case of Kenyatta 
International Journal of Business and Management Review

Vol.8, No.5, pp.1-14, July 2020

Published by ECRTD-UK

Print ISSN: 2052-6393(Print), Online ISSN: 2052-6407(Online)

University, Kenya. The strategic Journal of Business and Change Management, 32(8), 183-212.

Mushtaq, A., Ahmad, N., \& Shafiq, M. (2015). Job satisfaction and work commitment among security agencies of Kashmir: a comparative study. European Academic Research, 2(11), 14660-14673.

Ngeny, P. K., Bonuke, R., \& Kiptum, G. K. (2017). Effect of working environment on job satisfaction among non-teaching staff in secondary schools in Keiyo south sub-county Kenya. American Based Research Journal, 6(10), 42-51.

Nyaboga, E. N., Osero, P. O., \& Ajowi, J. (2015). Analysis of Working Conditions of Support Staff in Public Secondary Schools in Nyamira County, Kenya. The International Journal of Innovation Education and Research, 3(7). Retrieved from http://ijier.net/ijier/article/view/403

Ofori, D., \& Aryeetey, M. (2014). Recruitment and selection practices in small and medium sized enterprises: perspectives from Ghana. International Journal of Business Administration, 2(3), 45-60.

Omari, S., K'Obonyo, P., \& Kidombo, H. (2012). The moderating role of organisational justice on the relationship between age, locus of control and employee outcomes. DBA Africa Management Review, 2(3), 42-54.

Omolo, J. (2012). Regional disparities in employment and human development in Kenya. Canadian Journal of Business and Economics, 1(1) 1-17.

Otieno, D. (2013, September). Kenya, land offake goods, fake leaders, fake smiles. Retrieved from Article ID=2000092585\&story_title Kenya- land-of-fake-goods-fake-leaders-fake-smiles

Patimah, S. (2015). The influence of recruitment and selection on the performance of state elementary school principal's Bandar Lampung. Scientific Jou. Peuradeun - Int. Multidisp. Jou., 3, 165-190.

Syed, Z., \& Jama, W. (2012). Universalistic perspective of HRM and organizational performance: meta-analytical study. International Bulletin of Business Administration, 13, 47-57.

Tarigan, V., \& Ariani, D. W. (2015). Empirical study of the relations between Job Satisfaction, Organisational Commitment and Turnover Intention. Journal of Advances in Management and Applied Economics, 5(2), 21-42.

Tzafrir, S. S. (2006). A universalistic perspective for explaining the relationship between HRM practices and firm performance at different points in time. Journal of Managerial Psychology, 21(2), 109-130. 